\title{
Transposition
}

Musique et Sciences Sociales

$1 \mid 2011$

Polyphonie et société

\section{Pour une histoire culturelle de la musique.}

Entretien avec Karen Painter

Towards a cultural history of music. Interview with Karen Painter

Igor Contreras Zubillaga and Elsa Rieu

\section{(2) OpenEdition}

Journals

Electronic version

URL: http://journals.openedition.org/transposition/421

DOI: $10.4000 /$ transposition.421

ISSN: 2110-6134

Publisher

CRAL - Centre de recherche sur les arts et le langage

Electronic reference

Igor Contreras Zubillaga and Elsa Rieu, "Pour une histoire culturelle de la musique. », Transposition

[Online], 1 | 2011, Online since 01 February 2011, connection on 14 November 2019. URL : http://

journals.openedition.org/transposition/421 ; DOI : 10.4000/transposition.421

This text was automatically generated on 14 November 2019.

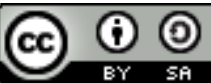

La revue Transposition est mise à disposition selon les termes de la Licence Creative Commons Attribution - Partage dans les Mêmes Conditions 4.0 International. 


\title{
Pour une histoire culturelle de la musique.
}

\author{
Entretien avec Karen Painter \\ Towards a cultural history of music. Interview with Karen Painter
}

Igor Contreras Zubillaga and Elsa Rieu

Professeure de musicologie à l'université du Minnesota, Karen Painter s'intéresse aux relations entre musique, écoute et idéologie dans l'Allemagne des $\mathrm{XIX}^{\mathrm{e}}$ et $\mathrm{XX}^{\mathrm{e}}$ siècles. Du début du XIX à la Vienne "fin-de-siècle", de la Première à la Seconde Guerre mondiale, elle déchiffre l'histoire des significations culturelles conférées à l'objet musical par l'élite intellectuelle bourgeoise, tout en interrogeant la dimension politique des débats - aussi bien dans le cadre des réflexions du socialisme austro-allemand que durant la période nazie. Ses nombreux ouvrages, essais et articles, sont caractérisés par une forte réflexivité méthodologique, qui met en œuvre une véritable approche pluridisciplinaire de l'objet musical ressortant aussi bien du domaine de l'histoire que de celui de la musicologie. Cet entretien a constitué pour nous l'occasion de l'interroger sur son parcours personnel, sur sa vision de la musicologie, mais également sur quelques points fondamentaux de son travail. De ce dialogue émane la figure d'une musicologue soucieuse de replacer l'étude de la musique au sein de la discipline historique, et d'engager son objet dans les débats épistémologiques et historiographiques contemporains.

\section{Entretien}

IgOR CONTRERAS ZUBiLlagA \& ELSA RIEU - In your research, you combine diverse methodological approaches, drawing upon social and cultural history, and upon musicology. Thus, in order to write your last essay, Symphonic Aspirations: German Music and Politics, 1933-1945, you carried out an important work on the historical sources (largely reviews of symphonies published in newspapers) that you address through the prism of shifts in mentalities, using other kinds of sources from the time, philosophical in particular. 
Musical analysis holds an important position in your writings. Could you tell us how your approach has formed? Which influences would you like to claim?

Karen Painter - My interest in musical discourse goes back, indirectly, to undergraduate training at Yale, where I studied philosophy-courses on the philosophy of language (Wittgenstein) and aesthetics (especially Adorno), as well as existentialism were memorable-and music.

My graduate work at Columbia University was strictly musicology, which through the early 1990s meant score study, with historical context that was largely based on composers. Increasingly, however, I found myself drawn to projects in which the language of musical listening could come under scrutiny. I became fascinated by constructions of the cultural and social relevance of music, which I first encountered in writings by Carl Dahlhaus. I felt drawn to historical texts (especially reviews and other writings for a wide musical public) in order to reconstruct experiences of musical listening-a task that to me, at least-was more important than charting my own encounter with musical works, even though I found inspiration in the questions asked by "new musicologists", and Susan McClary's dramatic and powerful writing in particular.

ICZ \& ER - When you undertake research, which approach do you apply first, the historical one or the musicological one? Would you say, for example, that the results provided by your historical research determine your musical analysis, by supplying new categories? Or is it the other way around?

KP - Ideally, I think, there would be no methodological difference between historical and musicological lines of inquiry. Historians who research musical subjects while avoiding any engagement with the music per se, risk becoming collectors or a type of biographer writ large: however useful their sources and command of detail, their interpretation of the materials will be flawed-in my view-as cultural or intellectual history. In most cases, I have begun with a pivotal work, so that the documents surrounding its performances are bountiful and relevant to mapping the terrain of a generation, or a musical concept. Occasionally, an aesthetic conundrum lies at the heart of a project, for example, whether and how composers writing in a "modernist" idiom became engaged with political and social goals in interwar Germany and Austria.

ICz \& ER - What, then, is the specificity of music as a cultural object?

KP - Investigation of music within culture typically involves ideological claims about cultural values and relationships. The temporal medium of music gives it a particular relevance to ideology, understood as a set of ideas intended to bring about change through a normative thought process. The old metaphor of music as rhetoric and oration had at its foundation the goal of convincing (or alienating, enraging and so on) the listener over time, and here I think musical listening can replicate the process of being absorbed into an ideological framework. I prefer to focus on the act of listening, and now the composer's intentions, in large part because the performance of a work (choice of repertoire, relationship to current events and political context) is a more reliable measure.

ICz \& ER - The main topic of your research is bourgeois musical culture in Germany. You explore its development in your essay on biographies of Mozart, ${ }^{1}$ and its shifts, in particular 
during the "long" transition from the 19th to the 20th century. How did you develop an interest in the subject?

KP - In 1992, I wrote a seminar paper for Maynard Solomon that compared the transmission of anecdotes in early Mozart biographies. The research, mostly in the rare book room of the New York Public Library's music division, was painstaking: I copied out passages from biographies in chronological order, tracing a line of development back to the two "authoritative" sources, which were themselves partly fictionalized; an author might elect to omit an inappropriate anecdote or detail, or insert commentary-whether a word or sentences. In particular in the early 19th century, when no virtually new sources became available to amateur biographers, the changes made from one author to the next seems to reflect cultural practice: how Germans wanted music to inculcate social and cultural values. This project revealed in vivid detail to me-at a time when discourse theory had not yet been applied to musicology-how writers on music aspired to make their subject relevant to the cultural ideologies of the day.

ICz \& ER - In your works, you are interested in the German-speaking realm, comprising Austria and Germany. Is it possible, in the musical sphere, to see this space as a unified one? Or are there national, or even regional, disparities?

KP - I have often been struck by the differences within this sphere-to oversimplify, the North/South dichotomy (Protestant/Catholic, discipline and austerity), with a focus on counterpoint versus the melodicism and sensuous orientation. I do see some regional differentiation in aesthetic and cultural values. This is a fruitful area for future research-not the same, tired categories of national identity but what orientations developed around other geographic units, whether a city or a region.

ICz \& ER - In Symphonic Aspirations, you provide a synthesis of the historical evolution of cultural-musical topics that were addressed in German-speaking discourse of critics, in particular by exploring reviews of symphonies. You affirm that, more than an essay on reception, your work is an attempt to reconstruct the listening habits and aesthetic values that critics wanted to instill in the public. Critics are not simply to be seen as mediators, their discourses represent real socio-political intervention in the cultural field. However, you mention many cases in which critics had divergent viewpoints from those of the public, in particular at the time of the premieres of Mahler's symphonies. While critics wrote negatives reviews in most cases, the premieres were real public successes. How can we understand this hiatus? Is it possible to assess the impact of criticism on the public?

KP - You point to an important methodological problem, I think, in reception history (to invoke a term I usually find limiting). Namely, an analysis of writings in newspapers and other genres aimed at a general public reveals very little about how the audience actually responded, apart from reporting on applause or other apparent reactions, which may or may not be accurate. Nor do we know whether the efforts of critics to instill this or that ideology met any success.

ICz \& ER - More generally, by which means can we comprehend the real impact of music on society?

KP - Now that so many traditional reception sources (newspapers, journals, and books) are readily available on the Internet, the challenge for the next generation will be to dig in new places for accounts of music's actual response: diaries, letters, autobiographies, among other sources.

ICZ \& ER - You give a precise description of the process by which critical discourse encounters the musical "new", notably on the question of timbre at the turn of the century: since there is yet no appropriate analytical framework to describe such a phenomenon, 
music critics have recourse to procedures of personification or to very figurative vocabularies. Without wishing to revive the avant-garde paradigm, can we ask whether music, through its innovations, more advanced than its reception?

KP - The limitations of language in general, and the challenge of capturing sound in words in particular, lay at the center of aesthetic judgment in the first half of the nineteenth century. This sense of awe, so palpable from E.T.A. Hoffmann to Robert Schumann, disappears in the later nineteenth century, and remains rare in the early decades of the twentieth (even if it is constructed, as a topic in operatic plots). Metaphors-which in the years round 1800 conveyed the potent mix of emotion, sensuousness, and spirituality in music-more often served to express the frustration of the commentator, for the later generations, in effect, their failure to delineate precisely what they heard and whether it observed generic an aesthetic norms. It is helpful, moreover, to historicize the practice of musical analysis and exegesis, recognizing its growth in the 1820s and waning in the 1880s. The initial decades of the 19th century saw, especially in German cities, the founding of numerous bourgeois "societies" in which music played a central or exclusive role; musical listening and amateur performance thrived during the years that music itself was absent from or marginalized in many of the journals aimed at "cultivation". Music can be integral to society even without an existing venue for explaining its structure or meaning-and perhaps a similar situation holds today.

ICZ \& ER - In your work, you show how depending the time or the author's ideological orientation, we shift from music to discourse, or rather to a multitude of discourses. What about the inverse phenomenon? How does the discourse influence the world of musical composition?

KP - You make a fascinating point, and one I think that warrants much more attention. Some works that represent a paradigm shift in musical language, genre, or aesthetic framework, can be said to embed within their very structure the discourse on their innovation. Thus the critique of excess, fraught with moral claims, is so integral to some compositions that to reject the music on these grounds is superfluous (which is not to say that it never happened). One example is Mahler's Sixth Symphony, which supplies the mechanism for disciplining its own intensity in counterpoint, thematic work, and timbral differentiation: a formal design thatwhether conservative (as in the opening) or innovative (as in the finale)-is so clearly articulate as to impose structure on the superabundance of surface material.

ICZ \& ER - In the shift from music to discourse, is it possible to identify several levels of meaning, for example a literal and descriptive one which could be described as more or less unvarying despite changes in terminology and a more ideological and contextdependent level?

KP - You implicitly question the free rein to scholars who mine music reviews and writings for language that reflects political or cultural ideology. Sometimes a metaphor is just that, and our ears may be deaf to the irony or entertainment value in evocative language. I might, however, invert your elegantly worded model: the literal description of a music may be vary according to the audience and context, whereas underlying ideology may be more permanent and persistent.

ICZ \& ER - You pay close attention to diverse musical concepts such as timbre or polyphony. ${ }^{2}$ You show how such concepts, their meaning and references, are formed in a 
specific cultural and political context, and transform in other contexts. How do you choose these concepts?

KP - I am interested in how a generation comes to struggle over a single element of music: even if the diatribe is emblematic of several issues, the fact remains that circa 1900 timbre-or distinctive and prominent use of instrumental color-became a source of anxiety for many music critics, and soon thereafter polyphony.

ICz \& ER - The concept of genre is also central in your work, you often raise your issues through the prism of a particular genre. ${ }^{3}$ Does each genre have his own history? Furthermore, in the context of your research, do you think that the symphonic genre could have aroused more interest than the opera or chamber music?

KP - Musicologists have been hesitant to move away from the "great composer" model of history, even though historically genre has been a more important factor in organizing musical life for consumers and readers. The symphony was, to my mind, more prone to politicization than opera-which could address political topics in subject matter and theatrical ornament, less in structural terms. Put simply, a viewer becomes absorbed in an opera, whereas the symphony has had a richer metaphorical life, at least for German and Austrian audiences. Chamber music, with its claims of intimacy and other practical constraints, was not a sufficiently public genre to warrant intense politicization.

ICZ \& ER - You show, in particular through the case study of Mahler, how the discourse produced in a musical work can be transformed depending on the context. You also state that "few scholars would maintain that political meaning inheres in music, even if certain structures and procedures might allow, or disallow, a political interpretation of one sort or another." Could you explain this second point? Does this "loss of autonomy" imply the existence of a "pure" status of music in which it would only refer to itself?

KP - Although there is no consensus on this issue, I think it is useful to acknowledge that not all human expression is political-or, at least, the explicit inscription of political meaning into an artwork is the choice of the composer, performer, interpreter, or listener. Whether a music work is political, and that might mean, is hard to ascertain and is by no means stable over time.

ICz \& ER - You have worked on musical life in Germany under the Nazi regime. ${ }^{4}$ In works concerning "music and politics", there seems to be a tension between "politicized music" and "political music". How do you consider this tension in your own reflection?

KP - Musicologists, who live in the shadow of a paradigm that depended on the canon of great works, have focused on the political reception of music more than music composed to political ends. This focus brings institutional benefits, connecting these scholars (whether they are housed in a school of music or a department of music) to the musicians being classically trained and to the faculty and wider public that remains tied to the classical corpus. In my own case, an interest in aesthetics has steered me toward certain repertoire choices. But as historians, we need a more secure grounding in the musical practice within communities or regions of interest. This will be an important corrective over the next decades, especially as music remains largely on the sidelines in the discipline of history.

ICZ \& ER - Could you say a few words about your most recent research?

KP - I have become interested in countercurrents to the political history of music: attempts to escape from the prevailing orientation or mood via listening experiences in the concert hall, home, or another milieu. This research avoids resurrecting the old ideologies of music free from political contamination, because defying or even 
simply ignoring the politics of the day-say, nationalism-amounts to a political position as much as composing outright nationalistic music. But I think we need to develop a more richly textured narrative than the one-to-one correspondence implied in recent approaches to the politics of music, including my own. Another project involves the falsification of music's importance in the early nineteenth century: German music writers stressed the centrality of the art form (the sources we have relied upon, out our at peril, without recognizing the cultural agenda at work), at a time when we know it still had marginal status in the university and insecure status in some social spheres. Less well known, I think, is that journals for "cultivation" (Bildung) largely excluded music from its pages, and social societies that formed around music and literary aspirations enjoyed music-making but did not allow for the analysis and exegesis that were permitted for art history and literature.

\section{BIBLIOGRAPHY}

\section{Bibliographie sélective}

\section{Ouvrages personnels}

Symphonic Aspirations: German Music and Politics, 1933-1945, Cambridge, Massachusetts, London, Harvard University Press, 2007.

Late Thoughts Reflections on Artists and Composers at Work, (en collaboration avec Thomas Crow), Los Angeles, Getty Research Institute, 2006.

Mahler and His World, Princeton, Princeton University Press, 2002.

\section{Contributions dans des ouvrages collectifs}

« Musical Aesthetics and National Socialism », in ILLIANO, Roberto et SALA, Massimiliano (ed.), Music and Dictatorship in Europe and Latin America, Turnhout, Brepols, 2009, p. 121-140.

" On Creativity and Lateness », in CROW, Thomas et PAINTER, Karen (ed.), Late Thoughts:

Reflections on Artists and Composers at Work, Los Angeles, Getty Research Institute, 2006, p. 1-11.

«W. A. Mozart's Beethovenian Afterlife: Biography and Musical Interpretation in the Twilight of Idealism ", in CROW, Thomas et PAINTER, Karen (ed.), Late Thoughts: Reflections on Artists and Composers at Work, Los Angeles, Getty Research Institute, 2006, p. 117-143.

« Jewish Identity and Anti-Semitic Critique in the Austro-German Reception of Mahler, 1900-1945 », in BARHAM, Jeremy (ed.), Perspectives on Gustav Mahler, Hants, Ashgate Press, 2005, p. $175-194$.

«Beyond the Bourgeoisie: Social Democracy and Musical Modernism in Interwar Austria and Germany ", in BERGER, Karol et NEWCOMB, Anthony (ed.), Music and the Aesthetics of Modernity, Cambridge, Harvard Music Department, 2005, p. 165-200.

" The 'Mozart Effect' and the Culture of Classical Music », in STENZL, Jürg (ed.), A Global View of Mozart: Mozart und Nordamerika, Salzburg, State of Salzburg, 2004, p. 30-37. 
" 'Songs of a Prisoner': Luigi Dallapiccola and the Politics of Voice under Fascism » (en collaboration avec Charles S. Maier), in ILLIANO Roberto (ed.), Italian Music during the Fascist Period, Turnhout, Brepols, 2004, p. 567-588.

«Genre and Aesthetics in the Lied around 1900: The Reception of Mahler's Kindertotenlieder », in SPONHEUER, Bernd et STEINBECK, Wolfram (ed.), Gustav Mahler und das Lied, Bonn, Peter Lang, 2003, p. 89-102.

" The Aesthetics of Mass Culture: Mahler's Eighth Symphony and its Legacy », in PAINTER, Karen (ed.), Mahler and His World, Princeton, Princeton University Press, 2002, p. 127-156.

« Mahler's German-Language Critics », (en collaboration avec Bettina Varwig), in PAINTER, Karen (ed.), Mahler and His World, Princeton, Princeton University Press, 2002, p. 268-379.

« Form, Innovation, Modernism: Early responses to Schoenberg's First String Quartet », in BRINKMANN, Reinhold et WOLFF, Christoph (ed.), Music of My Future: The Schoenberg Quartets and Trio, Cambridge, Harvard Music Department, 2000, p. 25-38.

\section{Articles}

"Mozart at Work: Biography and a Musical Aesthetic for the Emerging German Bourgeoisie », Musical Quarterly, 86, N 1, 2002, p. 186-235.

« Contested Counterpoint: 'Jewish' Appropriation and Polyphonic Liberation », Archiv für Musikwissenschaft, 58, N³, 2001, p. 201-230.

«Symphonic Ambitions, Operatic Redemption: Mathis der Maler and Palestrina in the Third Reich », Musical Quarterly, 85, N 1, 2001, p. 117-166.

" The Sensuality of Timbre: Responses to Mahler and Modernity at the Fin de siècle ", 19th Century Music, 18, N³, 1995, p. 236-256.

\section{NOTES}

1. «Mozart at work: Biography and a Musical Aesthetic for the Emerging German Bourgeoisie », in The Musical Quaterly, 86, $\mathrm{N}^{\circ} 1,2002$, p. 186-235.

2. See for example «Beyond the Bourgeoisie: Social Democracy and Musical Modernism in Interwar Austria and Germany ", in BERGER, Karol and NEWCOMB, Anthony (ed.), Music and the Aesthetics of Modernity, Cambridge, Harvard Music Department, distributed by Harvard University Press, 2005, p. 165-200; "Contested Counterpoint: 'Jewish' Appropriation and Polyphonic Liberation », in Archiv für Musikwissenschaft, 58, N³, 2001, p. 201-230; « The Sensuality of Timbre: Responses to Mahler and Modernity at the Fin de siècle ", in 19th Century Music, 18, N³, 1995, p. 236-256.

3. See in particular «Genre and Aesthetics in the Lied around 1900: The Reception of Mahler's Kindertotenlieder ", in SPONHEUER, Bernd and STEINBECK, Wolfram (ed.), Gustav Mahler und das Lied, Bonn, Peter Lang, 2003, p. 89-102; «The Aesthetics of Mass Culture: Mahler's Eighth Symphony and its Legacy ", in PAINTER, Karen (ed.), Mahler and His World, Pinceton, Princeton University Press, 2002, p. 127-156; «Form, Innovation, Modernism: Early responses to Schoenberg's First String Quartet ", in BRINKAMNN, Reinhold and WOLFF, Christoph (ed.), Music of My Future: The Schoenberg Quartets and Trio, Cambridge, Harvard Music Department distributed by Harvard University Press, 2000, p. 25-38.

4. See in particular Symphonic Aspirations: German Music and Politics, 1933-1945, Cambridge, Massachusetts, London, Harvard University Press, 2007; "Symphonic Ambitions, Operatic Redemption: Mathis der Maler and Palestrina in the Third Reich ", in Musical Quarterly, 85, $\mathrm{N}^{\circ} 1$, 
2001, p. 117-166; "Musical Aesthetics and National Socialism », in ILLIANO, Roberto, et SALA, Massimiliano (ed.), Music and Dictatorship in Europe and Latin America, Turnhout, Brepols, 2010, p. 121-140.

\section{ABSTRACTS}

This interview with Karen Painter has provided us with the opportunity of inquiring about her personal trajectory, her views on musicology, and certain key aspects of her work. From this dialogue, there emerges a musicologist concerned about relocating the study of music within the discipline of history, and engaging her object of study in the wider epistemological and historiographic debates.

Au cours de cet entretien, nous avons interrogé Karen Painter sur son parcours personnel, sur sa vision de la musicologie, mais également sur quelques points fondamentaux de son travail. De ce dialogue émane la figure d'une musicologue soucieuse de replacer l'étude de la musique au sein de la discipline historique, et d'engager son objet dans les débats épistémologiques et historiographiques contemporains.

\section{INDEX}

Keywords: Vienna "fin-de-siècle", Germany, bourgeoisie, World War I, World War II, listening, cultural studies, music social history, ideology, Mahler, methodology, musicology, music and politics, nazism

Mots-clés: Vienne « fin-de-siècle », Allemagne, bourgeoisie, Première Guerre mondiale, Deuxième Guerre mondiale, écoute, histoire culturelle, histoire sociale de la musique, idéologie, Malher, méthodologie, musicologie, musique et politique, nazisme 